\title{
A numerical modelling study on regional mercury budget for eastern North America
}

\author{
X. Lin and Y. Tao \\ Kinectrics, 800 Kipling Avenue, Toronto, M8Z 6C4, Canada \\ Received: 16 January 2003 - Published in Atmos. Chem. Phys. Discuss.: 20 February 2003 \\ Revised: 17 April 2003 - Accepted: 12 May 2003 - Published: 26 May 2003
}

\begin{abstract}
In this study, we have integrated an up-to-date physio-chemical transformation mechanism of $\mathrm{Hg}$ into the framework of US EPA's CMAQ model system. In addition, the model adapted detailed calculations of the air-surface exchange for $\mathrm{Hg}$ to properly describe $\mathrm{Hg}$ re-emissions and dry deposition from and to natural surfaces. The mechanism covers $\mathrm{Hg}$ in three categories, elemental $\mathrm{Hg}\left(\mathrm{Hg}^{0}\right)$, reactive gaseous $\mathrm{Hg}(\mathrm{RGM})$ and particulate $\mathrm{Hg}(\mathrm{HgP})$. With interfacing to MM5 (meteorology processor) and SMOKE (emission processor), we applied the model to a 4-week period in June/July 1995 on a domain covering most of eastern North America. Results indicate that the model simulates reasonably well the levels of total gaseous Hg (TGM) and the specific $\mathrm{Hg}$ wet deposition measurements made by the $\mathrm{Hg}$ deposition network (MDN). Moreover, results from various scenario runs reveal that the $\mathrm{Hg}$ system behaves in a closely linear way in terms of contributions from different source categories, i.e. anthropogenic emissions, natural re-emissions and background. Analyses of the scenario results suggest that $37 \%$ of anthropogenically emitted $\mathrm{Hg}$ was deposited back in the model domain with $5155 \mathrm{~kg}$ of anthropogenic $\mathrm{Hg}$ moving out of the domain during the simulation period. Overall, the domain served as a net source, which supplied $\sim$ a half ton of $\mathrm{Hg}$ to the global background pool over the period. Our model validation and a sensitivity test further rationalized the rate constant for gaseous oxidation of $\mathrm{Hg}^{0}$ by hydroxyl radical $\mathrm{OH}$ used in the global scale modelling study by Bergan and Rodhe (2001). A further laboratory determination of the reaction rate constant, including its temperature dependence, stands as one of the important issues critical to improving our knowledge on the budget and cycling of $\mathrm{Hg}$.
\end{abstract}

Correspondence to: X. Lin

(Xiude.Lin@kinectrics.com)

\section{Introduction}

Atmospheric Mercury ( $\mathrm{Hg})$ exists primarily in inorganic forms with three states, i.e. $\mathrm{Hg}^{0}$ (elemental $\mathrm{Hg}$ ), $\mathrm{RGM}$ (reactive gaseous divalent $\mathrm{Hg}$ ) and $\mathrm{HgP}$ (particulate $\mathrm{Hg}$ ). Although the existence of methylated $\mathrm{Hg}$ has been reported, it only accounts for less than $3 \%$ of the total gaseous $\mathrm{Hg}$, except areas near emissions sources. On the other hand, monovalent $\mathrm{Hg}\left(\mathrm{Hg}^{+}\right)$is unstable in the atmosphere. Under normal atmospheric conditions, $\mathrm{Hg}^{0}$ is the main component of gaseous $\mathrm{Hg}$, and constitutes the majority of $\mathrm{Hg}$ in the atmosphere. RGM is readily dissolved into the water. Subsequently, it is involved in aqueous phase reactions, and is also subject to adsorption onto the elemental carbon aerosols. $\mathrm{HgP}$ is referred to as particulate solid $\mathrm{Hg}$, which can exist in both gaseous phase and aqueous phase. Now, it is well known that atmospheric $\mathrm{Hg}$, predominantly in the gaseous elemental form, has a global atmospheric residence time of about a year. Such a time scale leads to significant long-range transport of the atmospheric $\mathrm{Hg}$ and its deposition in the areas distant from major point sources (Fitzgerald et al., 1998). Numeric modelling stands as a useful tool to study the complex chemical transformation, transport and deposition processes of atmospheric $\mathrm{Hg}$.

$\mathrm{Hg}$ is released into the atmosphere from both anthropogenic and natural sources. While anthropogenic $\mathrm{Hg}$ is mainly contributed by chloral-alkali production, coal combustion and waste incineration, natural sources of $\mathrm{Hg}$ are volcanoes, soils, forests, lakes, rivers and oceans. It was estimated that about $5500 \mathrm{Mg}$ of $\mathrm{Hg}$ were emitted globally in 1995 (U.S. EPA, 1997). Recent studies have indicated that $\mathrm{Hg}$ re-emitted from various natural surfaces represents a very important part in the atmospheric $\mathrm{Hg}$ burden. Mason et al. (1994) suggested a global marine emission of $2000 \mathrm{Mg}$ year $^{-1}$. Lindberg et al. (1998) estimated an annual emission of 1400 to $3200 \mathrm{Mg}$ of $\mathrm{Hg}$ attributable to terrestrial origins (forests and soils). Apparently, in order to gain more 
Table 1. The Physio-Chemical Transformation Mechanism of Hg integrated into CMAQ and Associated Rate Constants

\begin{tabular}{|c|c|c|}
\hline Reaction (Process) & Constants & Reference \\
\hline $\begin{array}{l}\text { Gas-phase chemistry } \\
\mathrm{Hg}_{(\mathrm{g})}^{0}+\mathrm{Cl}_{2(\mathrm{~g})} \rightarrow \mathrm{RGM}_{(\mathrm{g})} \\
\mathrm{Hg}_{(\mathrm{g})}^{0}+\mathrm{O}_{3(\mathrm{~g})} \rightarrow .5 \mathrm{RGM}_{(\mathrm{g})}+.5 \mathrm{HgP}_{\text {(insoluble) }} \\
\mathrm{Hg}_{(\mathrm{g})}^{0}+\mathrm{H}_{2} \mathrm{O}_{2(\mathrm{~g})} \rightarrow \mathrm{RGM}_{(\mathrm{g})} \\
\mathrm{Hg}_{(\mathrm{g})}^{0}+\mathrm{OH}_{(\mathrm{g})} \rightarrow .5 \mathrm{RGM}_{(\mathrm{g})}+.5 \mathrm{HgP}_{(\text {insoluble) }}\end{array}$ & $\begin{array}{l}4.8 \times 10^{-18} \mathrm{~cm}^{3} \mathrm{molec}^{-1} \mathrm{~s}^{-1} \\
3.0 \times 10^{-20} \mathrm{~cm}^{3} \mathrm{molec}^{-1} \mathrm{~s}^{-1} \\
8.5 \times 10^{-19} \mathrm{~cm}^{3} \mathrm{molec}^{-1} \mathrm{~s}^{-1} \\
2.9 \times 10^{-14} \mathrm{~cm}^{3} \operatorname{molec}^{-1} \mathrm{~s}^{-1}\end{array}$ & $\begin{array}{l}\text { Calhoun and Prestbo (2001) } \\
\text { Hall (1995) } \\
\text { Tokos et al (1998) } \\
\text { see text }\end{array}$ \\
\hline $\begin{array}{l}\text { Gas-Droplet equiliblia } \\
\mathrm{Hg}_{(\mathrm{g})}^{0} \rightleftharpoons \mathrm{Hg}_{(\mathrm{aq})}^{0} \\
\mathrm{RGM}_{(\mathrm{g})} \rightleftharpoons \mathrm{RGM}_{(\mathrm{aq})} \\
\mathrm{Cl}_{2(\mathrm{~g})} \rightleftharpoons \mathrm{Cl}_{2(\mathrm{aq})}\end{array}$ & $\begin{array}{l}1.1 \times 10^{-1} \mathrm{M} \mathrm{atm}^{-1} \\
1.4 \times 10^{+6} \mathrm{M} \mathrm{atm}^{-1} \\
7.6 \times 10^{-2} \mathrm{M} \mathrm{atm}^{-1}\end{array}$ & $\begin{array}{l}\text { Seigneur et al. (1994) } \\
\text { Seigneur et al. (1994) } \\
\text { Lin and Pehkonen (1998) } \\
\end{array}$ \\
\hline $\begin{array}{l}\text { Ionic equilibria in aqueous phase } \\
\mathrm{Hg}^{2+}+\mathrm{SO}_{3}^{2-} \rightleftharpoons \mathrm{HgSO}_{3} \\
\mathrm{HgSO}_{3}+\mathrm{SO}_{3}^{2-} \rightleftharpoons \mathrm{Hg}_{2}\left(\mathrm{SO}_{3}\right)_{2}^{2-} \\
\mathrm{Hg}^{2+}+2 \mathrm{Cl}^{-} \rightleftharpoons \mathrm{HgCl}_{2} \\
\mathrm{Hg}^{2+}+\mathrm{OH}^{-} \rightleftharpoons \mathrm{HgOH}^{+} \\
\mathrm{HgOH}^{+}+\mathrm{OH}^{-} \rightleftharpoons \mathrm{Hg}(\mathrm{OH})_{2} \\
\mathrm{HgOH}^{+}+\mathrm{Cl}^{-} \rightleftharpoons \mathrm{HgOHCl}\end{array}$ & $\begin{array}{l}2.0 \times 10^{-13} \mathrm{M} \\
4.0 \times 10^{-12} \mathrm{M} \\
1.0 \times 10^{-14} \mathrm{M}^{2} \\
2.51 \times 10^{-11} \mathrm{M} \\
6.31 \times 10^{-12} \mathrm{M} \\
3.72 \times 10^{-8} \mathrm{M}\end{array}$ & $\begin{array}{l}\text { Smith and Martell (1976) } \\
\text { Smith and Martell (1976) } \\
\text { Lin and Pehkonen (1999) } \\
\text { Smith and Martell (1976) } \\
\text { Smith and Martell (1976) } \\
\text { Smith and Martell (1976) }\end{array}$ \\
\hline $\begin{array}{l}\text { Chlorine reactions in aqueous phase } \\
\mathrm{Cl}_{2(\mathrm{aq})}+\mathrm{H}_{2} \mathrm{O} \rightleftharpoons \mathrm{HOCl}+\mathrm{Cl}^{-}+\mathrm{H}^{+} \\
\mathrm{HOCl} \rightleftharpoons \mathrm{OCl}^{-}+\mathrm{H}^{+}\end{array}$ & $\begin{array}{l}\mathrm{k}=10^{-3.3} \\
\mathrm{k}=10^{-7.5}\end{array}$ & $\begin{array}{l}\text { Lin and Pehkonen (1998) } \\
\text { Lin and Pehkonen (1998) }\end{array}$ \\
\hline $\begin{array}{l}\text { Hg oxidation in aqueous phase } \\
\mathrm{Hg}_{(\mathrm{aq})}^{0}+\mathrm{O}_{3(\mathrm{aq})} \rightarrow \mathrm{Hg}_{(\mathrm{aq})}^{2+}+\text { products } \\
\mathrm{Hg}_{(\mathrm{aq})}^{0}+{ }^{*} \mathrm{OH}_{(\mathrm{aq})} \rightarrow \mathrm{Hg}_{(\mathrm{aq})}^{2+}+\text { Products } \\
\mathrm{Hg}_{(\mathrm{aq})}^{0}+\mathrm{HOCL}_{(\mathrm{aq})} \rightarrow \mathrm{Hg}_{(\mathrm{aq})}^{2+}+\mathrm{Cl}_{(\mathrm{aq}}^{-}+\mathrm{OH}_{(\mathrm{aq})}^{-} \\
\mathrm{Hg}_{(\mathrm{aq})}^{+}+\mathrm{OCL}_{(\mathrm{aq})}^{-} \rightarrow \mathrm{Hg}_{(\mathrm{aq})}^{2+}+\mathrm{OH}_{(\mathrm{aq})}^{-}\end{array}$ & $\begin{array}{l}4.7 \times 10^{7} \mathrm{M}^{-1} \mathrm{~s}^{-1} \\
2.4 \times 10^{9} \mathrm{M}^{-1} \mathrm{~s}^{-1} \\
2.09 \times 10^{6} \mathrm{M}^{-1} \mathrm{~s}^{-1} \\
1.99 \times 10^{6} \mathrm{M}^{-1} \mathrm{~s}^{-1}\end{array}$ & $\begin{array}{l}\text { Munthe (1992) } \\
\text { Gardfeldt et al. (2001) } \\
\text { Lin and Pehkonen (1998) } \\
\text { Lin and Pehkonen (1998) }\end{array}$ \\
\hline $\begin{array}{l}\text { Hg reduction in aqueous phase } \\
\mathrm{HgSO}_{3(\mathrm{aq})} \rightarrow \mathrm{Hg}_{(\mathrm{aq})}^{0}+\text { Products } \\
\mathrm{Hg}(\mathrm{OH})_{2(\mathrm{aq})}+\mathrm{h} v \rightarrow \mathrm{Hg}_{(\mathrm{aq})}^{0}+\text { Products } \\
\mathrm{Hg}_{(\mathrm{aq})}^{2+}+{ }^{*} \mathrm{HO}_{2} \rightarrow \mathrm{Hg}_{(\mathrm{aq})}^{0}+\text { Products }\end{array}$ & $\begin{array}{l}\mathrm{T} \cdot \mathrm{e}^{31.971-12595 / \mathrm{T}} \mathrm{s}^{-1} \\
6.0 \times 10^{-7} \mathrm{~s}^{-1} \text { (Maximum) } \\
1.1 \times 10^{4} \mathrm{M}^{-1} \mathrm{~s}^{-1}\end{array}$ & $\begin{array}{l}\text { Van Loon et al. (2000) } \\
\text { Bullock and Brehme (2002) } \\
\text { Pehkonen and Lin (1998) }\end{array}$ \\
\hline $\begin{array}{l}\text { Sorption equilibrium in aqueous phase } \\
\mathrm{RGM}_{(\mathrm{aq})}+\mathrm{ATM} \rightleftharpoons \mathrm{HgP}_{(\text {soluble) }}\end{array}$ & $\mathrm{k}=34 \mathrm{Lg}^{-1} ; \mathrm{ATM}=0.02 \mathrm{gL}^{-1}$ & Seigneur et al. (2001) \\
\hline
\end{tabular}

accurate insight into the $\mathrm{Hg}$ budget and, thereafter, to design suitable abatement strategies, it is imperative to place anthropogenic emissions into a proper perspective. In this context, modelling studies on a regional scale need to appropriately include the important component of $\mathrm{Hg}$ emissions from natural surfaces.

To study the transport and deposition of the atmospheric $\mathrm{Hg}$ in Europe and the United States, several regional modelling studies have been carried out. While employing the anthropogenic emission inventories and providing valuable information on $\mathrm{Hg}$ chemistry, transport and deposition, some studies did not include detailed descriptions on the reemissions of $\mathrm{Hg}$ from natural surfaces. In general, the natural re-emissions were either included in the global back- ground (Bullock et al., 1997; Bullock, 2000; Petersen et al., 1998, 2001; Seigneur et al., 2001) or highly parameterized by a latitude and season dependence (Shannon and Voldner, 1995). Recently, Xu et al. (2000) integrated a Hg component into the Sarmap Air Quality Model (SAQM) (Chang et al., 1996). In their work, a parameterized $\mathrm{Hg}$ mechanism similar to the one of Petersen et al. (1995) was adopted. However, significant improvement was made in the estimation of reemissions of $\mathrm{Hg}$ from natural surfaces. Exchanges of $\mathrm{Hg}$ between air and the earth surface were explicitly calculated to depict its emissions and dry deposition from and to the surfaces. Most recently, Bullock and Brehme (2002) developed a regional $\mathrm{Hg}$ model based on the framework of a state-of-the science regional air quality model, the US EPA's Community 
Multi-scale Air Quality (CMAQ) model (Byun and Ching, 1999). In their model, a detailed physio-chemical mechanism of $\mathrm{Hg}$ involving both gaseous and aqueous phases was included to provide a more accurate description of the atmospheric $\mathrm{Hg}$ in three states $\left(\mathrm{Hg}^{0}\right.$, $\mathrm{RGM}$ and $\left.\mathrm{HgP}\right)$. Again, predetermined boundary conditions were used to represent the contributions to the atmospheric $\mathrm{Hg}$ burden from both global background and natural emissions that originated within the model domain. In the present study, we have further advanced their work by integrating a set of treatments for the atmosphere-surface exchange of $\mathrm{Hg}$. The modelling system was applied to a domain covering most of eastern North America. This paper describes our model structure, a preliminary validation of the model, a quantitative estimation of regional $\mathrm{Hg}$ budget and an investigation on the reaction rate constant of the important gaseous oxidation of $\mathrm{Hg}$ by hydroxyl radical $\mathrm{OH}$ and its impact on the atmospheric $\mathrm{Hg}$ modelling practice.

\section{Hg mechanism integrated into the CMAQ model sys- tem}

CMAQ is an advanced regional air quality modelling system. It was developed by the Atmospheric Modeling Division of the U.S. EPA (Byun and Ching, 1999) to simulate the transport, chemical transformation and deposition of air pollutants. Built on a "one-atmosphere" approach, CMAQ is so comprehensive in scope that it allows for the simulation of acid deposition, $\mathrm{O}_{3}$ and photochemical oxidants, and fine/coarse particulate matter at spatial scales ranging from urban to regional. CMAQ can be constructed within a computational framework, named Models-3. The framework enables users to interact with the modelling system through a high-level graphical user interface. Through the graphics and visualization capabilities, the framework facilitates data transmission among the components of the system and analysis of model simulation results. However, CMAQ, like its emission preprocessor SMOKE, can also be run in a stand-alone mode by executing scripts, which comprise various UNIX shell commands. In our present study, the standalone CMAQ version of June 2001 is utilized as an integration platform. Among the options supported by CMAQ in gaseous phase chemical mechanisms and numerical chemistry solvers, we selected RADM2 as the chemical mechanism and the QSSA solver to solve the stiff chemical system. Further, a physio-chemical transformation mechanism of $\mathrm{Hg}$ is integrated into the platform.

The physio-chemical transformation mechanism of $\mathrm{Hg}$ integrated into the CMAQ model is presented in Table 1. It is generally similar to the one used by Bullock and Brehme (2002). The mechanism involves $\mathrm{Hg}$ in three categories, $\mathrm{Hg}^{0}$, RGM and HgP. Some differences from Bullock and Brehme (2002) in the detailed treatment of the mechanism exist and are worthy to be noted as follows.
1. We assume that particulate mercury consists of two components, a soluble one and an insoluble one. The co-existence of the two HgP components in the atmosphere is rationalized by the $\mathrm{Hg}$ sorption experiments (Seigneur et al., 1998).

2. Products of gaseous oxidation reactions of $\mathrm{Hg}^{0}(\mathrm{~g})$ with $\mathrm{O}_{3} / \mathrm{OH}$ are allocated into two parts, 50\% in RGM and $50 \%$ in insoluble $\mathrm{HgP}$. The division of the reaction products was based on the study by Hall (1995) and the recommendation of Travnikov and Ryaboshapko (2002).

3. A reaction rate constant of $8.7 \times 10^{-14} \mathrm{~cm}^{3} \mathrm{molec}^{-1} \mathrm{~s}^{-1}$ for $\mathrm{Hg}^{0}(\mathrm{~g})$ oxidation by hydroxyl radical $\mathrm{OH}$ was originally reported by Sommar et al. (2001). This rate constant together with a normal $\mathrm{OH}$ levels would lead to a $\mathrm{Hg}^{0}$ lifetime of about 4-7 months. It should be noted that this rate has not been confirmed independently by any other laboratories yet. Travnikov and Ryaboshapko (2002) cautioned the high rate value. Ryaboshapko et al (2002) suggested a further investigation on the rate constant. More significantly, Bergan and Rodhe (2001) used a global model to evaluate the potential role of the oxidation reactions of $\mathrm{Hg}^{0}$. They found that the oxidation rate of Sommar et al. (2001) is too large (by about a factor of 3 ) to reconcile the model calculations with the observed global distribution of $\mathrm{Hg}^{0}$ and divalent $\mathrm{Hg}$. Based on their findings, we set the rate constant at $2.9 \times 10^{-14} \mathrm{~cm}^{3} \mathrm{molec}^{-1} \mathrm{~s}^{-1}$ in the present study. Later on, a sensitivity test on the reaction rate constant will be conducted and discussed in Sect. 5 .

4. In addition to its production from the oxidation in gas phase, insoluble $\mathrm{HgP}$ is also emitted from anthropogenic sources. Dissolved RGM in cloud water is subject to adsorption onto the atmospheric particulate matter. The adsorption leads to the generation of soluble $\mathrm{HgP}$ that, subsequently, is subject to a desorption process. The resultant sorption equilibrium is represented by an adsorption coefficient $\left(\mathrm{k}=34 \mathrm{Lg}^{-1}\right)$ and an average particulate matter concentration in the cloud droplet of $0.02 \mathrm{~g} \mathrm{~L}^{-1}$ as recommended by Seigneur et al. (2001).

5. Based on Seigneur et al. (2001), $\mathrm{Cl}_{2}$ is set to $10 \mathrm{ppt}$ during the day; and 100 and $50 \mathrm{ppt}$ for the first layer and the layers above, respectively, at night over the ocean. As for the inland, a zero concentration is assumed. A concentration of $\mathrm{Cl}$ - in the cloud water of $1.0 \times 10^{-3} \mathrm{~g} \mathrm{~L}^{-1}$ is adopted from Bullock and Brehme (2002).

It is worth noting that the dry deposition of $\mathrm{Hg}^{0}$ was omitted in Bullock and Brehme (2002). The modelling study by $\mathrm{Xu}$ et al. (2000) suggested that the dry deposition of $\mathrm{Hg}^{0}$ could account for about $20 \%$ of the total $\mathrm{Hg}$ deposition. In the present study, we calculated the dry deposition 
velocity for $\mathrm{Hg}^{0}$ using a detailed treatment on the air-surface exchange of $\mathrm{Hg}^{0}$ as described in Sect. 4.

\section{Anthropogenic emissions of $\mathrm{Hg}$}

The model domain is shown in Fig. 1. Horizontally, the domain covers most of eastern North America and contains $78 \times 67$ grids with a grid spacing of 36-km. Vertically, it has 15 layers with varying thickness defined in the ?-coordinates and is stretching from the surface to about $15000 \mathrm{~m}$ above the ground. The anthropogenic emissions of $\mathrm{Hg}$ input to the model were compiled using SMOKE (version 1.4B). Two 1995 inventories, the US one and the Canadian one, were utilized in the compilation. The US inventory, acquired from US EPA, cover all three species of $\mathrm{Hg}$ for point, area and mobile sources. On the other hand, the Canadian Hg emissions inventory, provided by Environment Canada, only includes the emissions for total $\mathrm{Hg}$ from point sources. To speciate the total $\mathrm{Hg}$ into its three species, we assumed different partitions for different industrial sectors following the treatment of Seigneur et al. (2001). More specifically, 56/42/2 of the $\mathrm{Hg}^{0} / \mathrm{RGM} / \mathrm{HgP}$ partition was set for coal-fueled electric utilities; $95 / 5 / 0$ for chlor-alkali facilities; $85 / 10 / 5$ for ironsteel industry; 100/0/0 for mining industry; and 50/30/20 for chemical manufacturing industry. The last ratio also served as the default for any sources that were out of the 5 industry categories.

As for the Canadian area and mobile sources of $\mathrm{Hg}$, Environment Canada has pre-compiled a regional inventory for a $50 \mathrm{~km} \times 50 \mathrm{~km}$ grid domain. The Canadian area and mobile emissions were mapped onto the defined model domain. A 50/30/20 partition among the three $\mathrm{Hg}$ species was assumed. SMOKE was used to process US area sources, US mobile sources and US/Canada point sources for Hg. These processed anthropogenic $\mathrm{Hg}$ emissions were finally integrated together with the output from normal SMOKE runs for the conventional RADM2 species and the $\mathrm{Hg}^{0}$ re-emissions from natural surfaces generated from the process as described in Sect. 4. The integration resulted in netCDF-formatted emission files for inputting to CCTM (CMAQ's chemical transport model, the core model of CMAQ system).

\section{Re-emissions and Dry Deposition of $\mathrm{Hg}^{\mathbf{0}}$ from and to Natural Surfaces}

In the present study, we adopted the general approaches of $\mathrm{Xu}$ et al. (1999) to calculate the mass transfer (emissions and dry deposition) of $\mathrm{Hg}^{0}$ caused by the air-surface exchanges. Briefly, the Penman-Monteith equation for evaportranspiration rate (Monteith and Unsworth, 1990) was employed in dealing with $\mathrm{Hg}^{0}$ emissions from plant canopies. An empirical relationship between the net $\mathrm{Hg}^{0}$ flux at the air-soil interface and soil temperature by Carpi and Lindberg (1998), calibrated by excluding the deposition flux, was used to estimate the emissions from soils. To calculate the emissions from water, an assumption, that the overall mass transfer coefficient of $\mathrm{Hg}^{0}$ at the air-water interface can be approximated by its mass transfer coefficient in the water, was made. In our view, this assumption can be further rationalized by applying Liss and Slater (1974)'s two-layer model to the interface and is supported by the data provided in Shannon and Voldner (1995) and Poissant et al. (2000).

To facilitate the evaluation of the mass transfer (emissions and dry deposition) of $\mathrm{Hg}^{0}$, we modified MCIP, the meteorology chemistry interface processor of the CMAQ modelling system, by integrating the algorithms of air-surface $\mathrm{Hg}^{0}$ exchanges. The modified MCIP generated natural re-emissions and dry deposition velocity of $\mathrm{Hg}^{0}$. One of MCIP's original output files, METCRO2D, was expanded to include this additional information. As being input to CCTM runs, the file was also used to generate the netCDF-formatted emission input files as described in Sect. 3.

It is worth noting that there are two main differences from $\mathrm{Xu}$ et al. (1999) in calculations of $\mathrm{Hg}^{0}$ fluxes. The first is related to the quantification of $\mathrm{Hg}^{0}$ content in surface soil water. To compute the emissions from the plant canopies using the evaportranspiration rate, the $\mathrm{Hg}^{0}$ concentrations in the surface soil water need to be defined. Xu et al. (1999) set a "universal" soil water $\mathrm{Hg}^{0}$ concentration such that it had a value of $100 \mathrm{ng} \mathrm{l}^{-1}$ for a minimum water stress case. To provide more reasonable geographical variations for the $\mathrm{Hg}^{0}$ concentration, we linked the soil contamination to the deposition of $\mathrm{Hg}$. Because of relatively short lifetimes of RGM and $\mathrm{HgP}$ compared to Hgo, we assumed that, as an approximation at the first order, the $\mathrm{Hg}^{0}$ content in surface soil water at a concerned location would be proportional to the product between the strength of a contributing anthropogenic $\mathrm{RGM} / \mathrm{HgP}$ source and the squared reciprocal of the distance between the contributing source and the concerned location.

A geographical distribution of the summed product was then generated by adding the contributions from all anthropogenic RGM and $\mathrm{HgP}$ sources within the modelling domain for each grid of the domain. According to the field study of Poissant and Casimir (1998), the $\mathrm{Hg}$ contents in surface soil water in southern Quebec, as derived from measured fluxes of $\mathrm{Hg}$ and water vapour, were about $15 \mathrm{ng} \mathrm{L}^{-1}$. This value was used to calibrate the summed variables to create a geographical distribution of $\mathrm{Hg}^{0}$ content in surface soil water for the modelling domain. The resultant distribution gives $70 \mathrm{ng} \mathrm{L}^{-1}$ of $\mathrm{Hg}^{0}$ in soil water for east-central Tennessee. This level is adequate to explain the observed emission rates from plant canopies (Lindberg et al., 1998). There is an uncertainty associated with the determination of the $\mathrm{Hg}^{0}$ content. As to be seen later, the re-emissions of $\mathrm{Hg}^{0}$ only account for a small part $(\sim 2 \%)$ of wet deposition over the entire domain due to the physio-chemical nature of $\mathrm{Hg}^{0}$. Therefore, we do not expect that the uncertainty involved would lead to a substantial difference in the wet deposition simulation of $\mathrm{Hg}$. 


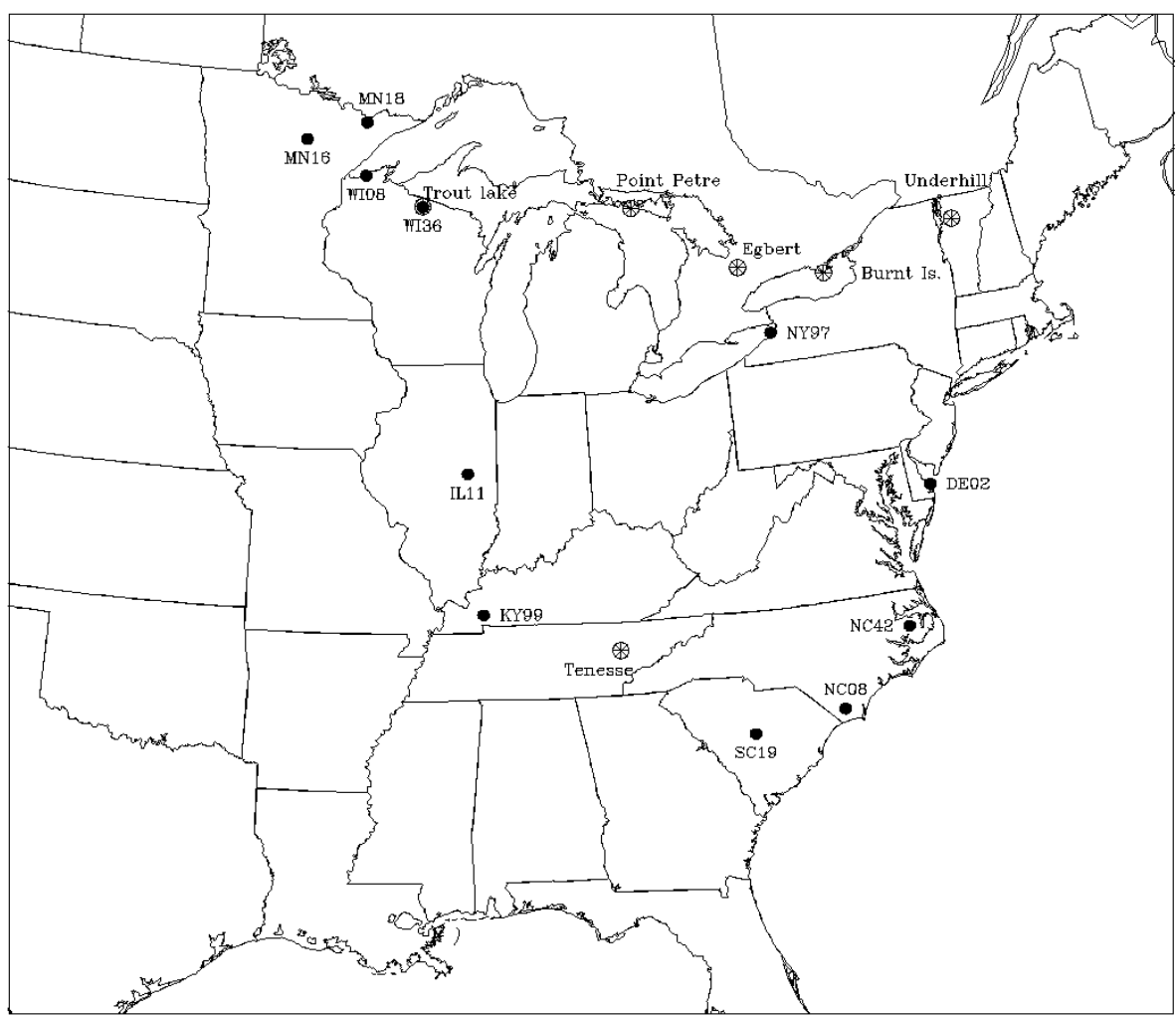

Fig. 1. The model domain. Also shown are the site locations of measurements used to evaluate the model performance (see text for details).

The second difference lies in the estimation of the mass transfer coefficient of $\mathrm{Hg}^{0}, \mathrm{~K}_{\mathrm{w}}$, in water when calculating the air-water exchanges. While Xu et al. (1999) used empirical formulae of Mackay and Yeun (1983) and Asher and Wanninkhof (1995), we adopted the approach by Poissant et al. (2000). Briefly, $\mathrm{K}_{\mathrm{w}}\left(\mathrm{cm} \mathrm{h}^{-1}\right)$ can be correlated with the mass transfer of $\mathrm{CO}_{2}$ across the airwater interface through (Wanninkhof et al. 1985, Hornbuckle et al., 1994)

$\mathrm{K}_{\mathrm{w}}=\left(0.45 U_{10}^{1.64}\right)\left[\mathrm{Sc}_{\mathrm{w}}\left(\mathrm{Hg}^{0}\right) / \mathrm{Sc}_{\mathrm{w}}\left(\mathrm{CO}_{2}\right)\right]^{0.5}$

where $U_{10}$ is the wind speed $\left(\mathrm{m} \mathrm{s}^{-1}\right)$ at $10 \mathrm{~m}$ and Sc's are the Schmidt numbers for $\mathrm{CO}_{2}$ and $\mathrm{Hg}^{0}$ in water, respectively. The Schmidt number of $\mathrm{CO}_{2}$ is calculated using the temperature-corrected dependency (Hornbuckle et al., 1994; Bidleman and McConnell, 1995)

$\mathrm{Sc}_{\mathrm{w}}\left(\mathrm{CO}_{2}\right)=0.11 T^{2}-6.16 T+644.7$

with $T$ in ${ }^{\circ} \mathrm{C}$. The Schmidt number of $\mathrm{Hg}^{0}$ is directly derived from its definition

$\mathrm{Sc}=v / D$

where the temperature $\left({ }^{\circ} \mathrm{C}\right)$ dependant $v$ (kinematic viscosity of water, $\mathrm{cm}^{2} \mathrm{~s}^{-1}$ ) and $D$ (diffusivity of $\mathrm{Hg}^{0}$ in water, $\left.\mathrm{cm}^{2} \mathrm{~s}^{-1}\right)$ are estimated by

$v=0.017 \exp (-0.025 T) \quad$ (Thibodeaux,1996)

$D=6.0 \times 10^{-7} T+10^{-5}$ (Kim and Fitzgerald, 1986)

The re-emissions of $\mathrm{Hg}^{0}$ in the model domain accumulated over a 4-week period from 20 June 1995 to 18 July
1995 are presented in Fig. 2. It is seen that the re-emissions substantially diminish in the northern part of the model domain. This is partially due to minimized agricultural coverage in the regions. As Xu et al. (1999) indicates, reemissions from agriculture are significantly larger than the re-emissions from forest and other land-use categories. The land-use effect is further enhanced by a less mercury content in surface soil water owing to much less anthropogenic sources than in the southern regions. In the eastern part of the model domain, relatively high re-emissions over the Atlantic Ocean coincide with higher average wind speed (not shown here). It is the high wind speed that causes the relatively high re-emissions through the wind dependence of the air-water exchange stated above.

\section{Model runs, results and discussion}

In the study, we carried out the regional $\mathrm{Hg}$ modelling for the time period of 16 June 1995 to 18 July 1995 . The modelling procedure started with a normal run of the meteorological processor MM5, a modified MCIP run and a normal run of the emission processor SMOKE. Then, a second SMOKE run with $\mathrm{Hg}$ emission inventories was conducted before executing the modified CCTM for Hg. To account for the global background of $\mathrm{Hg}$, we set boundary conditions of $0.2 \mathrm{ppt}$ for 


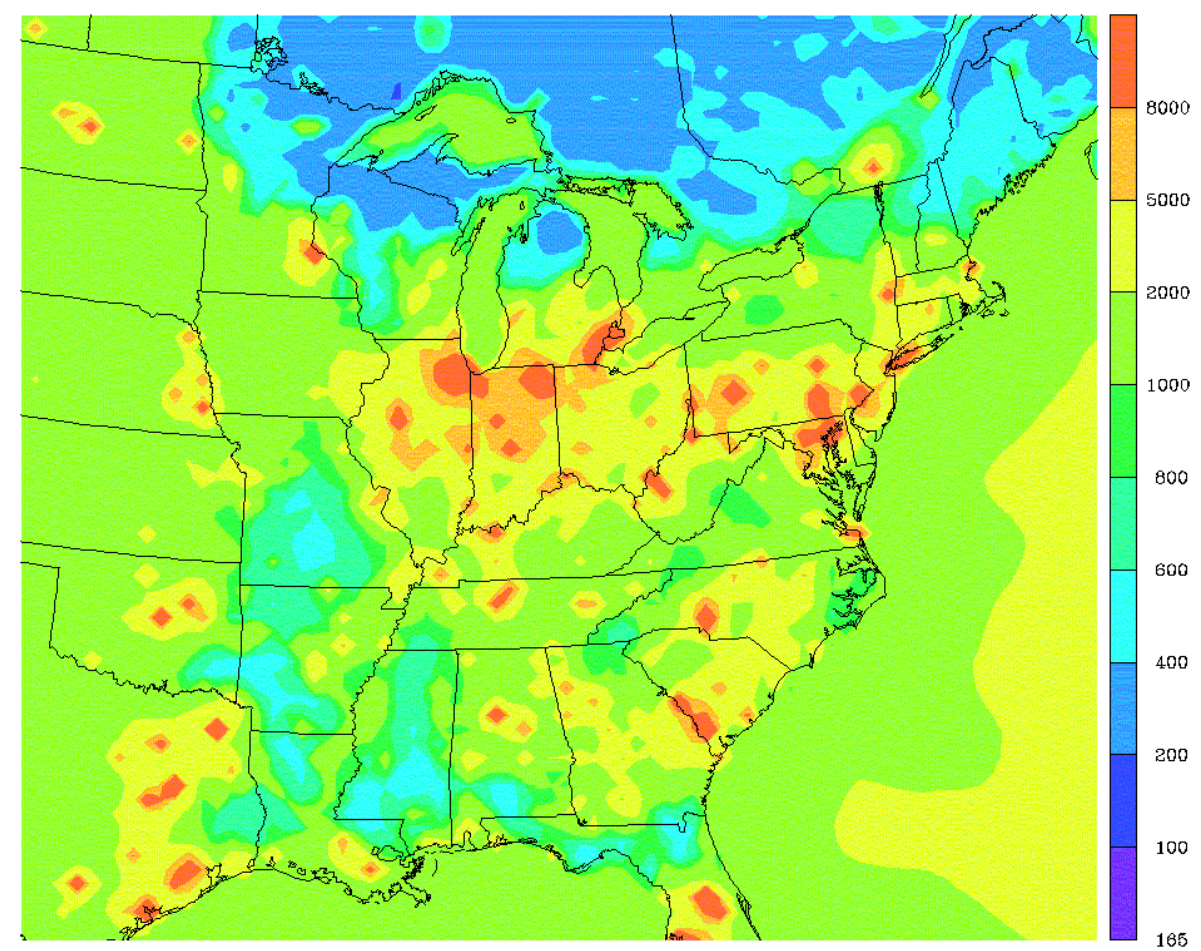

Fig. 2. Total re-emissions of $\mathrm{Hg}^{0}\left(\mathrm{ng} \mathrm{m}^{-2}\right)$ from natural surfaces over the period of 20 June 1995 to 18 July 1995.

$\mathrm{Hg}^{0}, 0.01 \mathrm{ng} \mathrm{m}^{-3}$ for both RGM and HgP. These background levels are similar to the ones chosen by Bullock and Brehme (2002) and Xu et al. (2000). The same values were assigned for $\mathrm{Hg}$ initial conditions. Although our model runs covered a 32-day period, the results from the first 4 days were excluded from analysis to avoid the unstable data in the initial "warm-up" period of a normal numerical modelling practice. To facilitate analysis, we conducted runs for 4 different scenarios. The 4 scenarios are

1. $\mathrm{S}_{0}$, a base-line scenario, which includes both anthropogenic emissions and re-emissions of $\mathrm{Hg}$ from natural surfaces as well as $\mathrm{Hg}$ boundary conditions;

2. $\mathrm{S}_{\mathrm{ba}}$, the same as $\mathrm{S}_{0}$ but without re-emissions of $\mathrm{Hg}$ from natural surfaces;

3. $\mathrm{S}_{\mathrm{bn}}$, the same as $\mathrm{S}_{0}$ but without anthropogenic emissions of $\mathrm{Hg}$; and

4. $S_{b}$, the same as $S_{0}$ but without both anthropogenic emissions and re-emissions of $\mathrm{Hg}$ from natural surfaces.

\subsection{Model validation}

To have a preliminary evaluation of the regional $\mathrm{Hg}$ model, we compared the model results from the $\mathrm{S}_{0}$ run with the measured ground level concentrations of total gaseous Hg (TGM) (Fitzgerald et al., 1991; Burke et al., 1995; Lindberg and
Stratton, 1998; Blanchard et al., 2002) and Hg wet deposition at the sites of $\mathrm{Hg}$ deposition network (MDN) (Lindberg and Vermette, 1995; http://nadp.sws.uiuc.edu/nadpdata/ mdnsites.asp). The measurement sites are plotted in Fig. 1 together with the model domain. While the TGM measurements represented general long-term averaged values, the MDN's data used in the study were those taken from JuneJuly of 1995. Since our model runs covered a period from 20 June 1995 to 18 July 1995 after excluding the "warm-up" period of model initiation, we can make a direct comparison between the modelled wet deposition of $\mathrm{Hg}$ and the MDN data.

For an illustration purpose, we plotted the total wet deposition of $\mathrm{Hg}$ over the 4-week period calculated from the S0 run in Fig. 3. In parallel, the total precipitation over the same period, which was derived from MM5 runs and was input into CMAQ, is plotted in Fig. 4. While the two variable fields show similar distribution patterns, some differences in the intensity exist in the east coastal and some central US regions. This disparity can be explained by the distribution of anthropogenic emission sources. It is known that the majority of $\mathrm{Hg}$ wet deposition are attributable to RGM and $\mathrm{HgP}$ and that the concentrations of RGM and $\mathrm{HgP}$ peak in the vicinities of the sources due to their relatively short lifetime. Therefore strengthened anthropogenic emissions in these regions, as shown in Fig. 5, compensated the relatively small precipitation and eventually led to significant wet deposition. 
Table 2. Comparisons of Modelled Total Wet Deposition of Hg and Averaged Ground Level Concentration of TGM over the Four-Week Modelling Period with Measurements

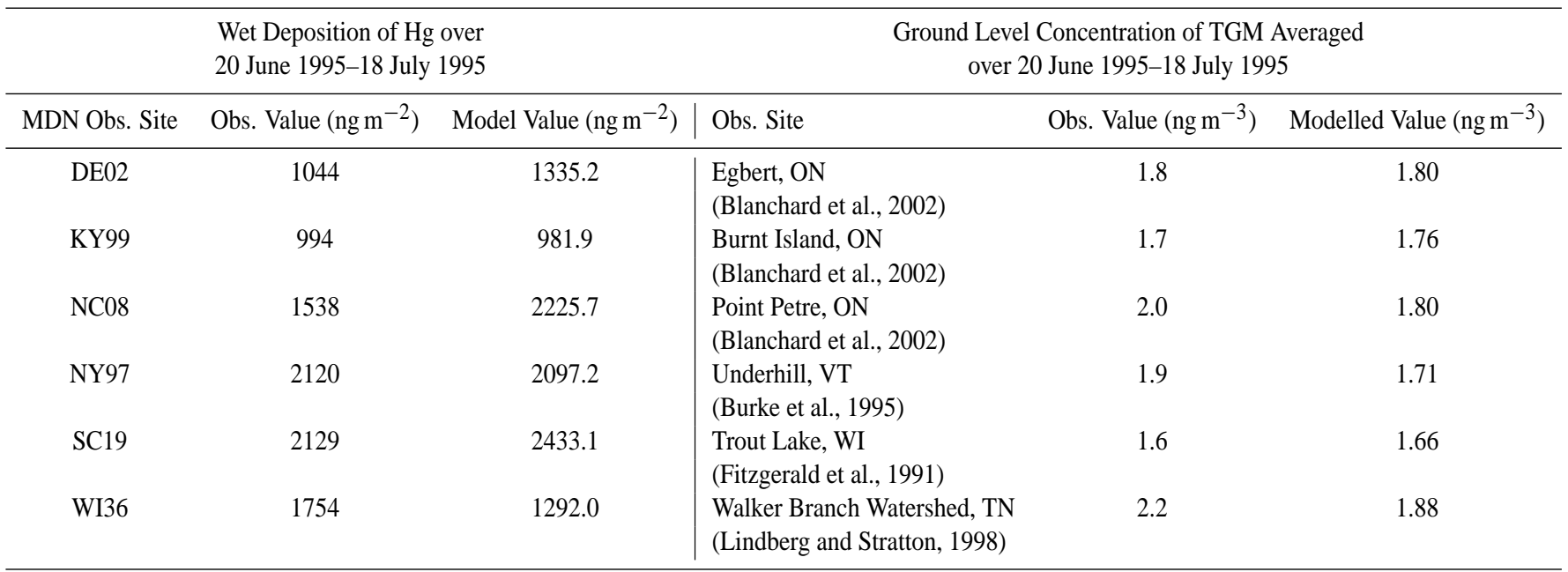

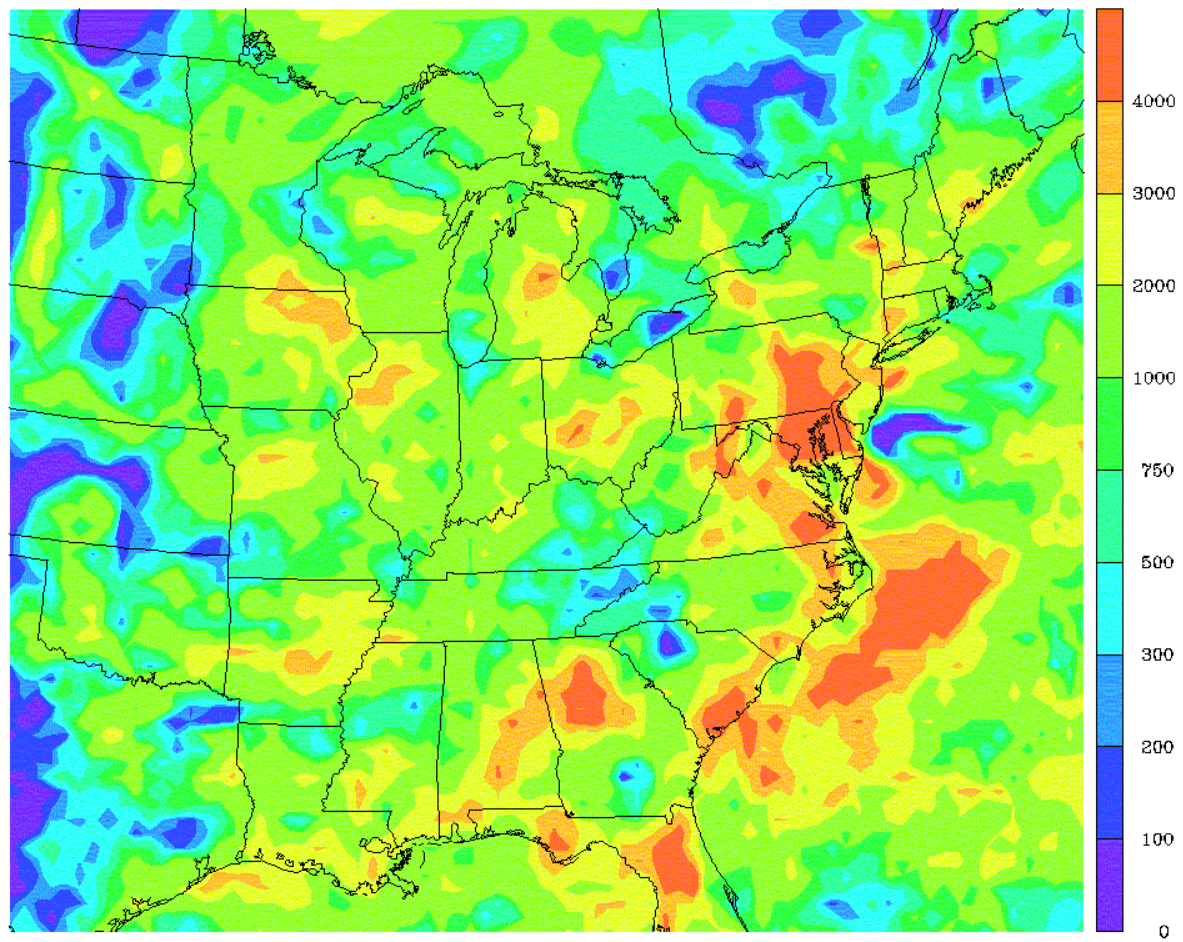

Fig. 3. Calculated total wet deposition of $\mathrm{Hg}^{0}\left(\mathrm{ng} \mathrm{m}^{-2}\right)$ over the period of 20 June 1995 to 18 July 1995.

Table 2 presents the comparisons of our model results from the scenario $S_{0}$ run with the field measurements. For ground level concentrations of TGM, the model results including both $\mathrm{Hg}^{0}$ and RGM were averaged over the modelling period. It is seen that the averaged TGMs derived from the model agree well with the measurements. In general, the modelled results are within $10 \%$ of the observations. As for the wet deposition of $\mathrm{Hg}$, six MDN sites reported valid total wet deposition of $\mathrm{Hg}$ for the entire 4-week modelling period. As shown in Table 2, the model did reasonably well in simulating the measured total wet deposition. The relative simulation errors lie between $-26 \%$ and $+45 \%$. Since MDN sites were usually measuring the $\mathrm{Hg}$ wet deposition on a weekly basis, analysis was also conducted for the weekly data. Among all MDN sites, there are 35 valid weekly deposition data involving 11 sites during the 4 -week period. 


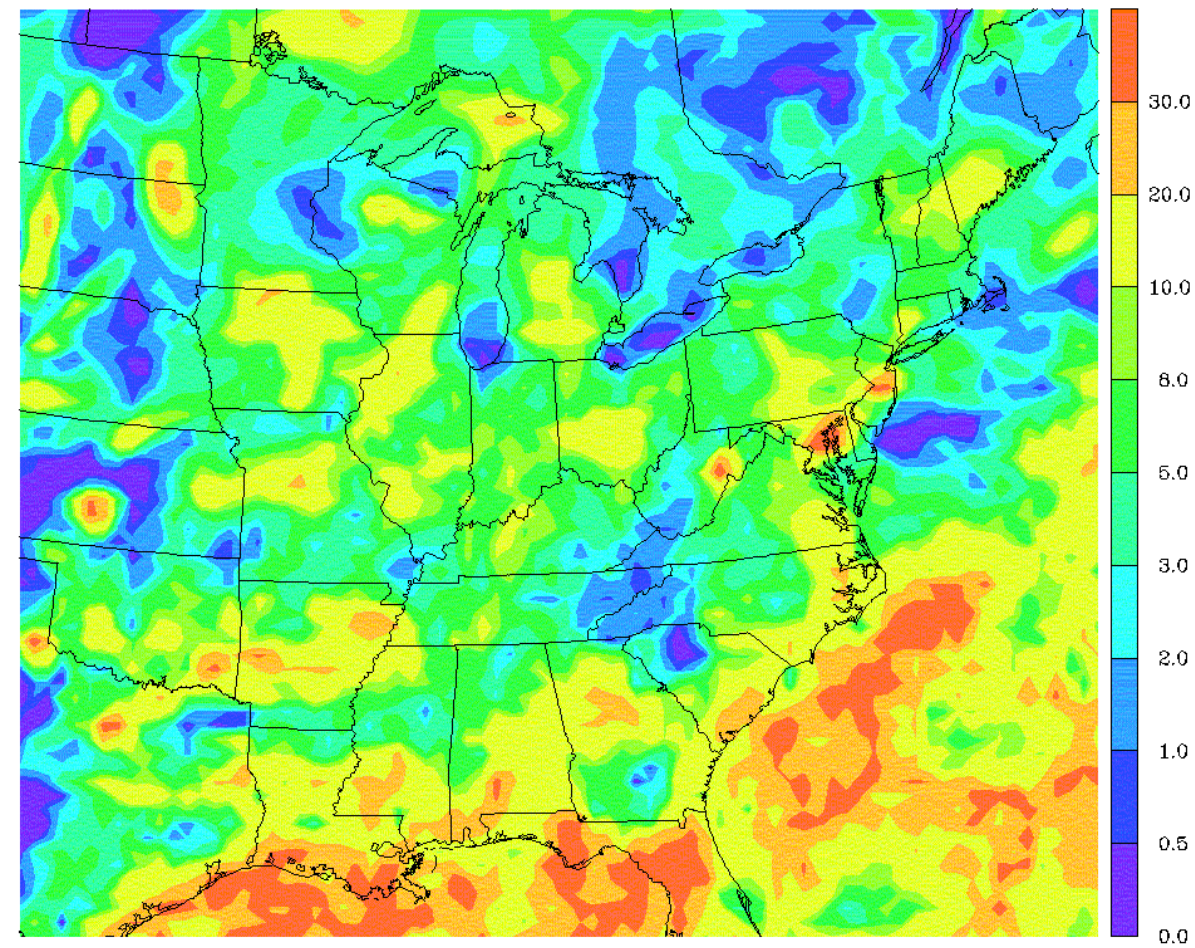

Fig. 4. Total precipitation (cm) over the period of 20 June 1995 to 18 July 1995, as inputted to CCTM.

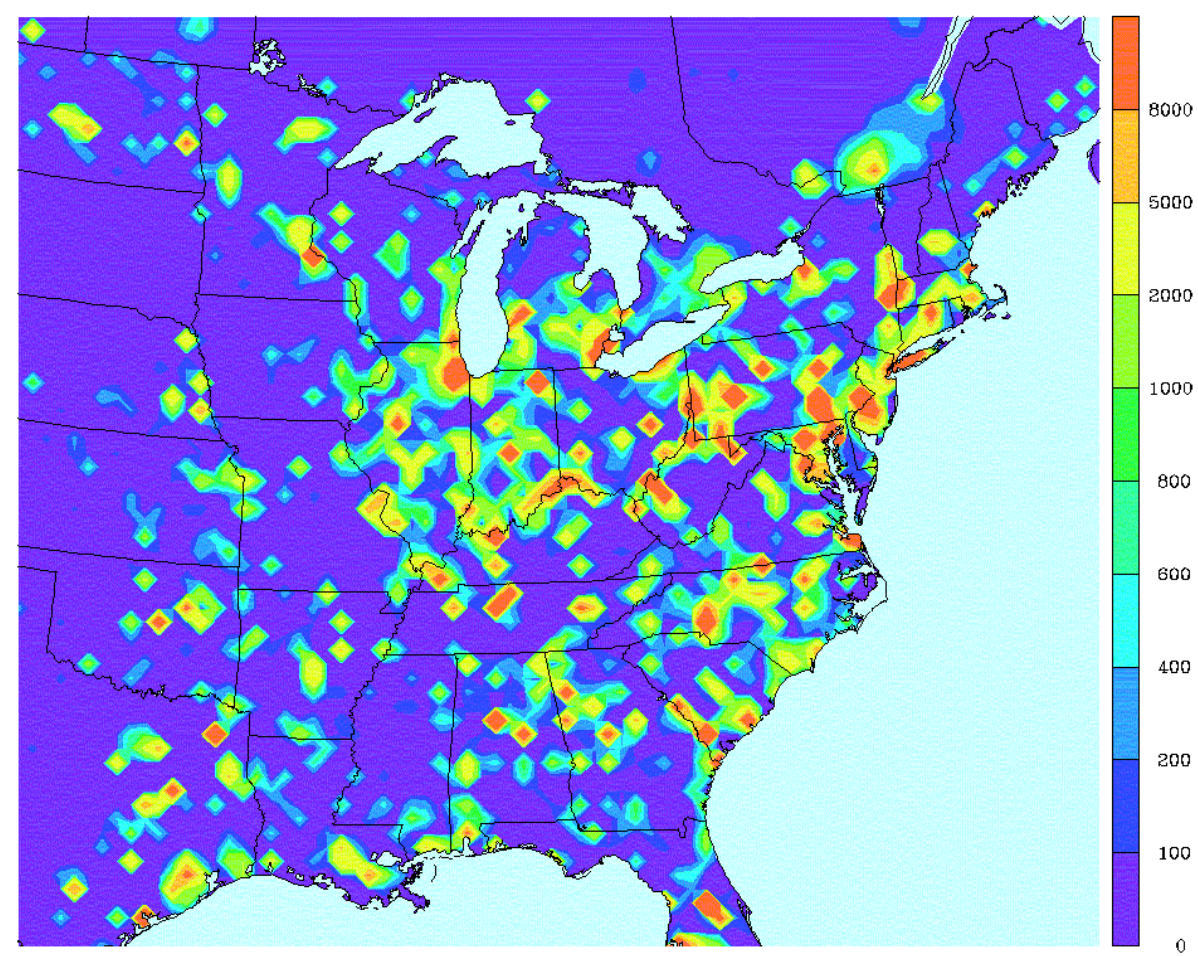

Fig. 5. Total anthropogenic emissions of RGM and $\operatorname{HgP}\left(\mathrm{ng} \mathrm{m}^{-2}\right)$ over the period of 20 June 1995 to 18 July 1995 , as inputted to CCTM. 
Table 3. Comparisons of Modelled Weekly Wet Deposition of $\mathrm{Hg}$ with Measurements from 11 MDN Sites

\begin{tabular}{ccccccccc}
\hline MDN Observation Site & \multicolumn{2}{c}{ 20 June-27 June } & \multicolumn{2}{c}{ 27 June-4 July } & \multicolumn{2}{c}{ 4 July-11 July } & \multicolumn{2}{c}{ 11 July-18 July } \\
& $\begin{array}{c}\text { Obs } \\
\left(\mathrm{ng} \mathrm{m}^{-2}\right)\end{array}$ & $\begin{array}{c}\text { Model } \\
\left(\mathrm{ng} \mathrm{m}^{-2}\right)\end{array}$ & $\begin{array}{c}\text { Obs } \\
\left(\mathrm{ng} \mathrm{m}^{-2}\right)\end{array}$ & $\begin{array}{c}\text { Model } \\
\left(\mathrm{ng} \mathrm{m}^{-2}\right)\end{array}$ & $\begin{array}{c}\text { Obs } \\
\left(\mathrm{ng} \mathrm{m}^{-2}\right)\end{array}$ & $\begin{array}{c}\text { Model } \\
\left(\mathrm{ng} \mathrm{m}^{-2}\right)\end{array}$ & $\begin{array}{c}\text { Obs } \\
\left(\mathrm{ng} \mathrm{m}^{-2}\right)\end{array}$ & $\begin{array}{c}\text { Model } \\
\left(\mathrm{ng} \mathrm{m}^{-2}\right)\end{array}$ \\
\hline DE02 & 40 & 179.6 & 646 & 64.5 & 0 & 0.0 & 358 & 1091.1 \\
IL11 & N/A & & 95 & 380.9 & N/A & & N/A & \\
KY99 & 36 & 577.2 & 425 & 0.0 & 533 & 0.0 & 0 & 404.7 \\
MN16 & 378 & 104.6 & 222 & 360.5 & 371 & 591.4 & N/A & \\
MN18 & N/A & & 347 & 510.9 & 182 & 317.4 & N/A & \\
NC08 & 130 & 293.6 & 286 & 473.0 & 548 & 388.2 & 574 & 1070.8 \\
NC42 & $1207^{*}$ & 846.8 & N/A & & $493 * *$ & 204.8 & N/A & \\
NY97 & 761 & 623.1 & 16 & 403.2 & 650 & 589.9 & 693 & 481.1 \\
SC19 & 972 & 1143.9 & 250 & 878.3 & 697 & 410.8 & 210 & 0.0 \\
WI08 & 161 & 0.3 & 383 & 432.1 & 207 & 224.5 & N/A & \\
WI36 & 234 & 366.0 & 0 & 29.7 & 227 & 234.2 & 1293 & 662.1 \\
\hline
\end{tabular}

* Sample dates 22 June 1995 to 29 June 1995

** Sample dates 06 July 1995 to 13 July 1995

The weekly data of the 11 sites are listed in Table 3 together with their modelled counterparts. A scatter plot with a leastsquares regression line and a forced regression line with zero intercept is presented in Fig. 6. This plot is indeed parallel to Fig. 5b of Bullock and Brehme (2002). The present calculated correlation coefficient is 0.46 , indicating an improvement over the correlation coefficient 0.329 by Bullock and Brehme (2002). More comparisons of statistics are summarized in Table 4. While Bullock and Brehme (2002) significantly over-predicted the mean value and the variability of the measured data, the present study improved the two statistics with a slight over-estimation of $5.2 \%$ and a slight under-estimation of $2.6 \%$, respectively. The improvement is reflected in all 4 quartiles.

The overall improvement mainly resulted from the reduced rate constant of the gaseous oxidation of $\mathrm{Hg}^{0}$ by $\mathrm{OH}$. As to be shown in a sensitivity analysis below, a reduction of the rate constant by two third of the value originally reported by Sommar et al. (2001) leads to a considerable decrease of $\sim 5000 \mathrm{~kg}$ in the total wet deposition over the simulation domain for the entire modelling period. At the same time, as a regional budget analysis in the next section indicates, this decrease is compensated by a small increase $(180 \mathrm{~kg})$ in the wet deposition due to the inclusion of the re-emissions from natural surfaces.

Despite the overall improvement introduced by a 3-fold reduction of the critical rate constant, the correlation coefficient between the measured and the modelled wet deposition of $\mathrm{Hg}$ is still low. As pointed out by Bullock and Brehme (2002), the wet deposition simulation is directly affected by the input meteorological data. For the above 35 weekly cases, we analyzed the correlation between the real precipitation depth $(\mathrm{cm})$ and the input precipitation depth. While the real data were retrieved from wet deposition data (ng m ${ }^{-2}$ ) and samples' concentration data $\left(\mathrm{ng} \mathrm{L}^{-1}\right)$ for $\mathrm{Hg}$, the model input was generated from MM5 runs. An analysis on the pair of precipitation data led to a Pearson correlation coefficient of 0.36 , which is comparably low with the one for the wet deposition of $\mathrm{Hg}$. On the other hand, the linear correlation analyses on the wet deposition of $\mathrm{Hg}$ and the precipitation depth resulted in Pearson correlation coefficients of 0.83 for the MDN measurement data and 0.72 for the model input/output. Evidently, an improvement in the modelled precipitation field would significantly improve the model performance for the wet deposition simulation of $\mathrm{Hg}$.

\subsection{Regional budget}

To investigate the regional budget of $\mathrm{Hg}$, we calculated the domain total deposition of $\mathrm{Hg}$ over the modelling period of 20 June 1995 to 18 July 1995 . The calculations were done for each of the 4 scenarios defined above. The resultant total deposition for all three components of $\mathrm{Hg}$ is presented in $\mathrm{Ta}$ ble 5 . The deposition was further segregated into the dry part and the wet part. Also shown in the table are total emissions released from the sources within the model domain during the simulation period. From the table, re-emissions of $\mathrm{Hg}$ from natural surfaces account for $60 \%$ of total $\mathrm{Hg}$ emissions or 1.5 times of anthropogenic $\mathrm{Hg}$ emissions. It is of interest to note that the $\mathrm{Hg}$ system behaves in a nearly linear way. Based on the four scenario definitions, the close linearity can be illustrated by comparing the summed value of $S_{0}$ and $S_{b}$ with the summed value of $S_{b a}$ and $S_{b n}$ for each of the deposition categories in Table 5. By subtracting the value of a variable in $S_{b}$ from its counterpart in another scenario, we estimated contribution to the variable from an emission component, which was added onto the $S_{b}$ to form the other scenario. More specifically, we calculated the contributions to 


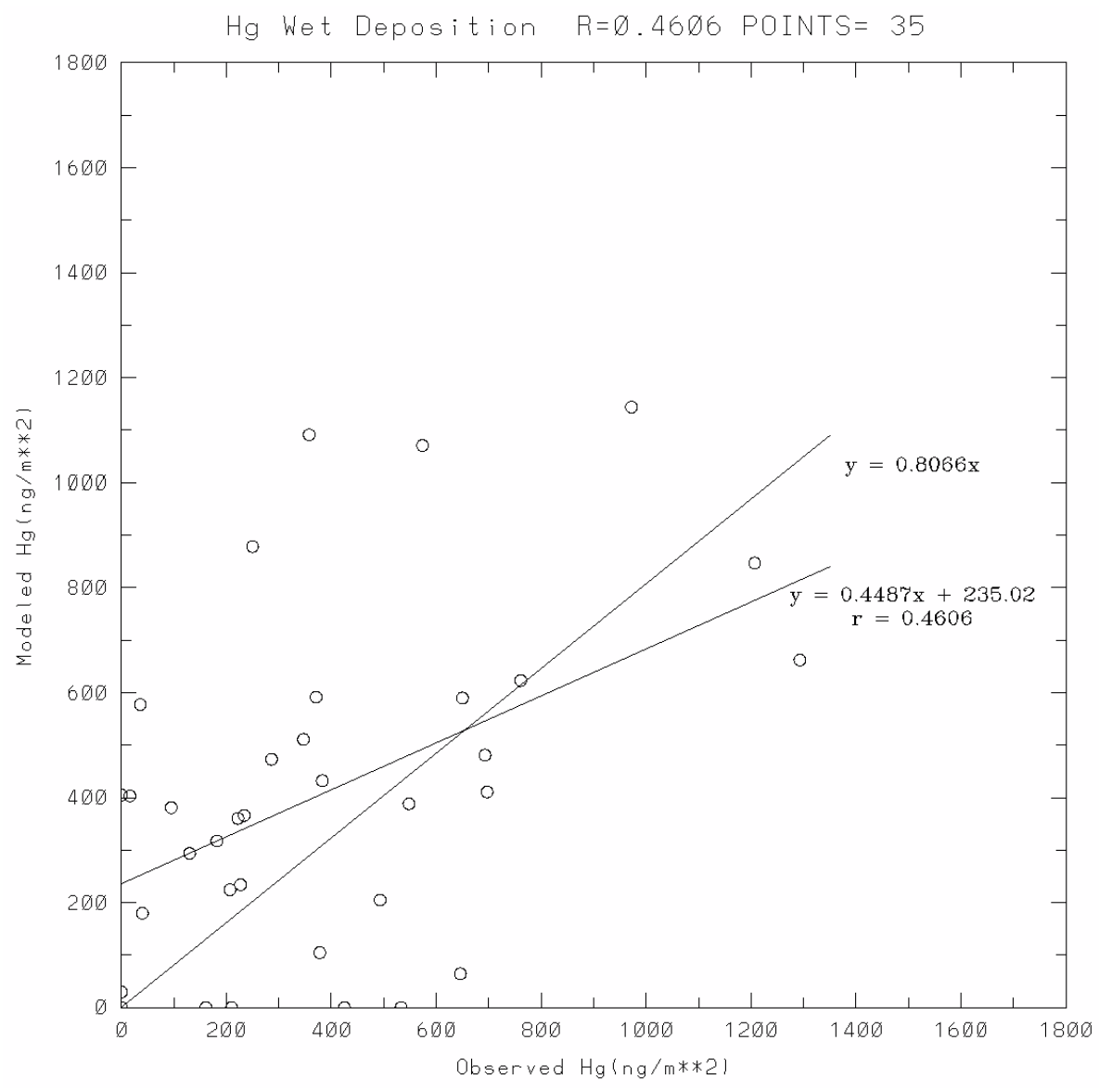

Fig. 6. Scatter plot of modelled versus measured wet deposition of $\mathrm{Hg}$. Also shown are a least-squares regression line and a forced regression line with zero intercept.

Table 4. Comparison of Statistics among MDN Measurements, Results of Bullock and Brehme (2002), Results from Baseline Run and Results from Sensitivity Test Run (see text for detail)

\begin{tabular}{|c|c|c|c|c|c|c|c|c|}
\hline \multirow[t]{2}{*}{ Sample \# } & \multirow[t]{2}{*}{ Data Source } & \multirow[t]{2}{*}{ Mean $\left(n g m^{-2}\right)$} & \multirow[t]{2}{*}{$\sigma$} & \multirow[t]{2}{*}{ Min. $\left(\right.$ ng m $^{-2}$ ) } & \multicolumn{3}{|c|}{ Percentile $\left(\mathrm{ng} \mathrm{m}^{-2}\right)$} & \multirow[t]{2}{*}{ Max. $\left(\operatorname{ng~m}^{-2}\right)$} \\
\hline & & & & & 25th & 50 th & 75 th & \\
\hline 35 & MDN Measurement & 389.3 & 327.3 & 0.0 & 171.5 & 347.0 & 561.0 & 1293.0 \\
\hline 35 & Bullock and Brehme (2002) & 623.7 & 621.1 & 0.0 & 202.1 & 482.5 & 759.7 & 2598.5 \\
\hline 35 & Baseline Run & 409.7 & 318.9 & 0.0 & 192.2 & 388.2 & 583.5 & 1143.9 \\
\hline
\end{tabular}

dry/wet deposition from anthropogenic emissions plus natural re-emissions, anthropogenic emissions only and natural re-emissions only, respectively. The estimated values are listed in the brackets in Table 5. In addition, the re-emissions and deposition of $\mathrm{Hg}$ from and to natural surfaces associated with the base-line scenario run are presented in Table 6 . From the two tables, one may observe the followings.

1. Among $8216 \mathrm{~kg}$ of $\mathrm{Hg}$ emitted anthropogenically, $3061 \mathrm{~kg}(37.3 \%)$ were directly deposited back in the domain. Accordingly, $62.7 \%$ of anthropogenic $\mathrm{Hg}$ $(5155 \mathrm{~kg})$ moved out of the domain and, subsequently were integrated into the background. This partition is similar to U.S. EPA (1997).

2. Among $12481 \mathrm{~kg}$ of naturally re-emitted $\mathrm{Hg}, 704 \mathrm{~kg}$ (5.6\%) were directly deposited back in the domain with $180 \mathrm{Kg}$ deposited though the wet process. A majority part $(94.4 \%)$ of the re-emitted $\mathrm{Hg}$ moved out of the domain and was integrated into the background.

3. The background contributed $16477 \mathrm{~kg}$ of $\mathrm{Hg}$ deposition in the domain, accounting for $81.4 \%$ of total deposition. 
Table 5. Domain Total Deposition of Hg Calculated over the Period of 20 June 1995 to 18 July 1995 from Four Scenario Runs

\begin{tabular}{|c|c|c|c|c|c|c|c|}
\hline \multirow[t]{2}{*}{ Scenarios } & \multirow[t]{2}{*}{$\begin{array}{l}\text { Emis. } \\
\text { within } \\
\text { Domain } \\
(\mathrm{Kg})\end{array}$} & \multicolumn{3}{|c|}{$\begin{array}{l}\text { Dry Deposition over Entire } \\
\text { Domain }(\mathrm{Kg}) \\
\text { (Bracketed values refer to } \\
\text { differences from the } \\
\left.\text { Background Scenario } S_{b}\right) \\
\end{array}$} & \multicolumn{3}{|c|}{$\begin{array}{l}\text { Wet Deposition over Entire } \\
\text { Domain }(\mathrm{Kg}) \\
\text { (Bracketed values refer to } \\
\text { differences from the } \\
\left.\text { Background Scenario } S_{b}\right)\end{array}$} \\
\hline & & $\mathrm{Hg}^{0}$ & RGM & $\mathrm{HgP}$ & $\mathrm{Hg}^{0}$ & RGM & $\mathrm{HgP}$ \\
\hline \multirow{3}{*}{$\begin{array}{l}\mathbf{S}_{0}: \\
\text { Base Line }\end{array}$} & \multirow{3}{*}{20697} & 6068 & 4277 & 159 & 1 & 3683 & 6048 \\
\hline & & \multicolumn{3}{|c|}{10503 (2230) } & \multicolumn{3}{|c|}{9733 (1529) } \\
\hline & & \multicolumn{6}{|c|}{20236 (3759) } \\
\hline \multirow{3}{*}{$\begin{array}{l}\mathbf{S}_{\text {ba: }}: \\
\text { Background+ } \\
\text { Anth. Emis. }\end{array}$} & \multirow{3}{*}{8216} & 5637 & 4192 & 155 & 1 & 3612 & 5940 \\
\hline & & \multicolumn{3}{|c|}{9985 (1712) } & \multicolumn{3}{|c|}{$9554 \quad(1350)$} \\
\hline & & \multicolumn{6}{|c|}{19538 (3061) } \\
\hline \multirow{3}{*}{$\begin{array}{l}\mathbf{S}_{\text {bn }} \text { : } \\
\text { Background+ } \\
\text { Re-Emis. }\end{array}$} & \multirow{3}{*}{12481} & 5921 & 2751 & 125 & 1 & 3154.6 & 5228 \\
\hline & & \multicolumn{3}{|c|}{8797 (524) } & \multicolumn{3}{|c|}{8384 (180) } \\
\hline & & \multicolumn{6}{|c|}{17181 (704) } \\
\hline \multirow{3}{*}{$\begin{array}{l}\mathbf{S}_{\mathrm{b}} \text { : } \\
\text { Background } \\
\text { only }\end{array}$} & & 5485 & 2666 & 121.5 & 1 & 3082.5 & 5120 \\
\hline & & \multicolumn{3}{|c|}{8273} & \multicolumn{3}{|c|}{8204} \\
\hline & & \\
\hline
\end{tabular}

4. While background contributions predominated, anthropogenic emissions contributed more than 5 and 7 times than the re-emissions to the dry deposition and the wet deposition, respectively.

5. While a total of $20697 \mathrm{~kg}$ of $\mathrm{Hg}$ was emitted, $20236 \mathrm{~kg}$ of $\mathrm{Hg}$ were received by the surface within the domain through deposition processes. This resulted in a net loss of about a half ton and, therefore, indicates the domain as a whole acting as a net supplier to the background pool of $\mathrm{Hg}$ for the 4-week simulation period. However, this "net source" conclusion should be dealt cautiously. The net contribution to the background pool only accounts for about $2 \%$ of the amount of $\mathrm{Hg}$ received or the amount of $\mathrm{Hg}$ emitted in the domain, and represents indeed a small difference between the two large numbers. Considering the uncertainties inherited in the study (such as the anthropogenic emission inventory, the formulation of re-emissions and dry deposition processes, and the precipitation field etc.) the sign of the small difference could be changed as some input data were altered.

6. As the cycling of $\mathrm{Hg}$ is concerned, the data in Table 6 indicate that the land surface within the model domain re-emitted $9120 \mathrm{~kg}$ of $\mathrm{Hg}$ while received $15932 \mathrm{~kg}$ of $\mathrm{Hg}$ during the 4-week simulation period. For the water surface, the re-emissions and deposition were $3361 \mathrm{~kg}$ and $4304 \mathrm{~kg}$, respectively. The $\mathrm{Hg}$ surplus status at the natural surfaces indicates an ongoing accumulation process in the land and the water, and is consistent with the general picture of the human and industrial activities in the region.
Table 6. Re-emissions and Deposition of Hg over the Period of 20 June 1995 to 18 July 1995 in the Base-Line Scenario Simulation

\begin{tabular}{cccc}
\hline & \multirow{2}{*}{ Re-Emissions } & \multicolumn{2}{c}{ Deposition } \\
& & Dry & Wet \\
\hline Land Surface & 9120 & 9341 & 6591 \\
& & \multicolumn{2}{c}{15932} \\
\hline Water Surface & 3361 & 1163 & 3141 \\
& & \multicolumn{2}{c}{4304} \\
\hline
\end{tabular}

\subsection{Sensitivity of rate constant of gaseous oxidation by $\mathrm{OH}$}

As mentioned previously, in their global modelling study, Bergan and Rodhe (2001) found that the rate constant of gaseous oxidation by $\mathrm{OH}$ of Sommar et al. (2001) is too large by about a factor of 3 to simulate the observed global distribution of $\mathrm{Hg}^{0}$ and divalent $\mathrm{Hg}$. Based on their findings, we set the rate constant at $2.9 \times 10^{-14} \mathrm{~cm}^{3} \mathrm{molec}^{-1} \mathrm{~s}^{-1}$ in the study. To shed light upon the impact of the rate constant on the model simulations, we reset the rate at $8.7 \times 10^{-14} \mathrm{~cm}^{3} \mathrm{molec}^{-1} \mathrm{~s}^{-1}$ and run the CCTM with emissions, initial/boundary conditions and all other inputs kept at the same values as Scenario $S_{0}$. Results indicated that the fast oxidation reactions led to more production of RGM and $\mathrm{HgP}$. Consequently, more dry and wet deposition was generated at the expense of $\mathrm{Hg}^{0}$. Over the entire modelling period, the domain total dry and wet depositions were $12068 \mathrm{~kg}$ and $14960 \mathrm{~kg}$, respectively. These numbers represent a $15.9 \%$ increase of the dry deposition and a $53.7 \%$ increase of the wet 
Table 7. Statistics Comparison between Baseline Run and Sensitivity Test Run

\begin{tabular}{ccccccc}
\hline & Bias $\left(\mathrm{ng} \mathrm{m}^{-2}\right)$ & Error $\left(\mathrm{ng} \mathrm{m}^{-2}\right)$ & Relative Bias & Relative Error & RMSE (ng m ${ }^{-2}$ ) & Index of Agreement \\
\hline Baseline $\left(\mathrm{S}_{0}\right)$ Run & 20.4 & 267.2 & 1.51 & 2.02 & 331.5 & 0.6745 \\
Sensitivity Test Run & 262.5 & 399.6 & 2.97 & 3.33 & 518.0 & 0.5996 \\
\hline
\end{tabular}

deposition. Accordingly, the domain averaged ground level concentration of TGM dropped by $0.054 \mathrm{ng} / \mathrm{m}^{3}(3.2 \%)$ from the $\mathrm{S}_{0}^{\prime} \mathrm{s}$ value. Under this circumstance, the domain would serve as a strong sink in the sense of a global budget with a net gain of $6331 \mathrm{~kg}$ of $\mathrm{Hg}$. This net gain would be equivalent to $30.6 \%$ of the amount emitted both anthropogenically and from natural surfaces within the domain. Evidently, such a large positive percentage is not consistent with the human and industrial activities within the region in a global context.

The model results from the sensitivity test run were also compared against the measurements. The calculated ground level concentrations of TGM for the 6 observation sites were $0.04-0.08 \mathrm{ng} / \mathrm{m}^{3}$ less than their counterparts from the $\mathrm{S}_{0}$ run. The drops in such a range did not practically weaken the model performance for TGM. The simulation of the wet deposition measurement, however, was significantly deteriorated. To illustrate the deterioration, we calculated bias, error, relative bias, relative error, root mean squared error (RMSE) and index of agreement (IOA) for model results from both the $\mathrm{S}_{0}$ run and the sensitivity test run. While bias, error, relative bias, relative error and RMSE follow their conventional definitions; IOA is defined as

$$
I O A=1-\frac{N(R M S E)^{2}}{\sum_{i=1}^{M}\left(\left|M_{i^{\prime}}\right|+\left|O_{i^{\prime}}\right|\right)^{2}}
$$

where $N$ is the total number of samples, $M_{i^{\prime}}$ and $O_{i^{\prime}}$ are the departures from the mean observed value of the modelled value and the observed value, respectively. A value of $\mathrm{IOA}=1$ indicates a perfect agreement and $\mathrm{IOA}=0$ indicates absolutely no agreement (Hedley et al., 1995). Calculated statistics are shown in Table 7. It is seen that the tripled rate constant caused much higher wet deposition of $\mathrm{Hg}$ at the MDN sites and worse agreement with the measurements than the $S_{0}$ run. As shown by the values of bias, the mean value of the 35 samples would be $262.5 \mathrm{ng} / \mathrm{m}^{2}$ higher than the measured mean compared to $20.4 \mathrm{ng} / \mathrm{m}^{2}$ higher in the $\mathrm{S}_{0}$ case. This over-prediction is even larger than the overestimation of $234.4 \mathrm{ng} / \mathrm{m}^{2}$ by Bullock and Brehme (2002) (as seen in Table 4), apparently due to the inclusion of the $\mathrm{Hg}$ re-emissions from natural surfaces in the study.

\section{Conclusions}

In the present study, we integrated an up-to-date physiochemical transformation mechanism of $\mathrm{Hg}$ and detailed cal- culations on the air-surface exchange of $\mathrm{Hg}^{0}$ into the framework of US EPA's CMAQ model system. An application of the constructed Hg model to a 4-week period in June/July 1995 indicated that the comprehensive model simulated reasonably well the specific wet deposition measurements of $\mathrm{Hg}$ at the MDN sites as well as the general ground level concentrations of TGM. Results from various scenario runs revealed that the $\mathrm{Hg}$ system behaves in a closely linear way in terms of the source contributors, i.e. anthropogenic emissions, natural re-emissions and background. Analyses on model results showed that $37 \%$ of anthropogenically emitted $\mathrm{Hg}$ were deposited back in the model domain with $63 \%(5155 \mathrm{~kg})$ of anthropogenic $\mathrm{Hg}$ moving out of the domain during the simulation period.

The results from the base-line run indicated that the domain as a whole served as a net source to supply about a half ton of $\mathrm{Hg}$ into the global background pool over the simulation period. This amount represents about $2 \%$ of the $\mathrm{Hg}$ amount received by the surfaces or the amount of $\mathrm{Hg}$ emitted in the domain. Considering the uncertainties involved, the sign of the small net source could be changed, as some input data would be altered. Moreover, the global background contributed more than $80 \%$ of the regional deposition of $\mathrm{Hg}$. The background dominance reflects the "long-living" nature of $\mathrm{Hg}$. Consequently, it implies that a proper $\mathrm{Hg}$ modelling needs to be performed on a large spatial scale such as a continental scale unless boundary conditions can be defined reasonably well.

It should be noted that the present study is subject to limitations or uncertainties as any similar modelling studies. These limitations or uncertainties are ranged widely from emissions, meteorology prediction, mechanism description, and deposition treatment to lack of dry deposition comparison. Following other significant pioneer works, we carried out this comprehensive regional modelling study by including the up-to-date physio-chemical transformation mechanism of $\mathrm{Hg}$ and the up-to-date treatment of $\mathrm{Hg}$ re-emission and dry deposition. Through the model validation and a sensitivity test, it emerges that the currently reported reaction rate constant of the gaseous oxidation of $\mathrm{Hg}^{0}$ by hydroxyl radical $\mathrm{OH}$ could be too large by a factor of 3 . Therefore, a further laboratory determination of the rate constant, including its temperature dependence, stands as one of the important issues critical to improving our understanding on the budget and cycling of $\mathrm{Hg}$. On the other hand, the present model will also benefit from more field studies on 
the air-surface exchange of $\mathrm{Hg}^{0}$. These studies will provide much valuable information to modify/ correct the assumptions or parameters employed in the model study such as the $\mathrm{Hg}$ content in surface soil water etc.

\section{References}

Asher, W. E. and Wanninkhof, R.: The effect of breaking waves on the analysis of dual-tracer gas exchange measurements, in AirWater Gas Transfer, (Eds) Jhne B. and Monahan E. C., Aeon Verlag, Hanau, pp. 517-528, 1995.

Bergan, T., Gallardo, L., and Rodhe, H.: Mercury in the global troposphere: a three-dimensional model study, Atmospheric Environment, 33, 1575-1585, 1999.

Bergan, T. and Rodhe, H.: Oxidation of elemental mercury in the atmosphere; Constraints imposed by global scale modelling, Journal of Atmospheric Chemistry, 40, 191-212, 2001

Bidleman, T. F. and McConnell, L. L.: Gas exchange of persistent organic pollutants, Science of the Total Environment, 159, 101$117,1995$.

Blanchard, P., Froude, F. A., Martin, J. B., Dryfhout-Clark, H., and Woods, J. H.: Four years of continuous total gaseous mercury (TGM) measurements at sites in Ontario, Canada, Atmospheric Environment, 36, 3735-3743, 2002.

Bullock, O. R. Jr., Benjey, W. G., and Keating, M. H.: The modeling of regional-scale atmospheric mercury transport and deposition using RELMAP, in Atmospheric Deposition of Contaminants to the Great Lakes and Coastal Waters, (Ed) Joel E. Baker, 323347, SETAC Press, Pensacola, 1997.

Bullock, O. R. Jr.: Modeling assessment of transport and deposition patterns of anthropogenic mercury air emissions in the United states and Canada, Science of the Total Environment, 259, 145157, 2000.

Bullock, O. R. Jr. and Brehme, K. A.: Atmospheric mercury simulation using the CMAQ model: formulation description and analysis of wet deposition results, Atmospheric Environment, 36, 2135-2146, 2002.

Burke, J., Hoyer, M., Keeler, G., and Scherbatskoy, T.: Wet deposition of mercury and ambient mercury concentration at site in the lake champlain basin, Water, Air \& Soil Pollution, 80, 353-362, 1995.

Byun, D. W. and Ching, J. K. S.: Science algorithms of the EPA models-3 community multiscale air quality (CMAQ) modeling system, EPA-600/R-99-030, US Environmental Protection Agency, 1999.

Calhoun, J. A. and Prestbo, E.: Kinetic study of the gas phase oxidation of elemental mercury by molecular chlorine. Report available from Frontier Geosciences inc., 414 Pontius Avenue N., Seattle, WA 98109, 2001.

Carpi, A. and Lindberg, S. E.: Application of a Teflon dynamic flux chamber for quantifying soil mercury flux:tests and results over background soil, Atmospheric Environment, 32, 873-882, 1998.

Chang, J. S., Jin, S., Li, Y., Beauharnois, M., Chang, K.-H., Huang, H.-C., Lu, C.-H., Wojcik G., Tanrikulu, S., DaMassa, J.: The SARMAP air quality model. Part I of SAQM final report. California Air resources Board, Sacramento, CA. 1996

Fitzgerald, W. F., Vandal, G. M., and Mason, R. P.: Atmospheric cycling and air-water exchange of $\mathrm{Hg}$ over mid-continental lacustrine regions. Water, Air \& Soil Pollution, 56, 745-767, 1991.
Fitzgerald, W. F., Engstrom, D. R., Mason, R. P., and Nater, E. A.: The case for atmospheric mercury contamination in remote areas. Environmental Science and Technology, 32(1), 1-7, 1998.

Gardfeldt K., Sommar J., Stromberg, D., and Feng, X.: Oxidation of atomic mercury by hydroxyl radicals and photoinduced decomposition of methylmercury in the aqueous phase, Atmospheric Environment, 35, 3039-3047, 2001.

Hall, B.: The gas phase oxidation of elemental mercury by ozone, Water, Air, \& Soil Pollution, 80, 301-315, 1995.

Hedley, M., McLaren, R., Jiang, W., Singleton, D. L.: Evaluation of the MC2-CALGRID photochemical modeling system, Report PET-1361-95S, National Research Council Canada, 1995.

Hornbuckle, K. C., Jeremiason, J. D., Sweet, C. W., and Eisenreich, S. J.: Seasonal variations in air-water exchange of polychlorinated biphenyls in Lake superior, Environmental Science Technology 28, 1491-1501, 1994.

Kim, J. P. and Fitzgerald, W. F.: Sea-air partitioning of mercury in the equatorial Pacific Ocean. Science, 231, 311-330, 1986.

Lin, C. and Pehkonen, S.: Oxidation of elemental mercury by aqueous chlorine (HOCl/OCl-): Implications for tropospheric mercury chemistry, Journal of Geophysical Research, 103, 28093 28 102, 1998.

Lin, C. and Pehkonen, S.: The chemistry of atmospheric mercury: a review, Atmospheric Environment, 33, 2067-2079, 1999.

Lindberg, S. E. and Stratton, W. J.: Atmospheric mercury speciation and behavior of reactive gaseous mercury in ambient air, Environmental Science and Technology, 21, 49-57, 1998.

Lindberg, S. E., Hanson, P. J., Meyers, T. P., and Kim, K. H.: Air/surface exchange mercury vapor over forests The need for a reassessment of continental biogenic emissions, Atmospheric Environment, 32, 895-908, 1998.

Lindberg, S. and Vermette, S.: Workshop on sampling mercury in precipitation for the National Atmospheric Deposition Program, Atmospheric Environment, 29, 1219-1220, 1995.

Liss, P. S. and Slater, P. G.: Flux of gases across the air-sea interface, Nature 247, 181-184, 1974.

Mackay, D. and Yeun, A. T. K.: Mass transfer coefficient correlations for volatilization of organic solutes from water. Environmental Science and Technology, 17, 211-217, 1983.

Mason, R. P., Fitzgerald, W. F., and Morel, F. M.: The biogeochemical cycling of elemental mercury: anthropogenic influences, Geochemica, 58, 3191-3198, 1994.

Monteith, J. L. and Unsworth, M. H.: Principles of environmental physics, (Ed) Butterworth-Heinemann, 1990.

Munthe, J.: The aqueous oxidation of elemental mercury by ozone, Atmospheric Environment, 26A, 1461-1468, 1992.

Pehkonen, S. and Lin, C.: Aqueous photochemistry of mercury with organic acid, Journal of Air and Waste Magement Assoc., 48, 144-150, 1998.

Petersen, G., Iverfeldt, A., and Munthe, J.: Atmospheric mercury species over central and northern Europe. Model calculations and comparison with observations from the Nordic air and precipitation network for 1987 and 1988, Atmospheric Environment, 29, 47-67, 1995.

Petersen, G., Munthe, J., Pleijel, K., Bloxam, R. and Vinod Kumar, A.: A comprehensive Eulerian modeling framework for airborne mercury species: Development and testing of the tropospheric chemistry module (TCM), Atmospheric Environment, 32, 829$843,1998$. 
Petersen, G., Bloxam, R., Wong, S., Munthe, J., Kruger, O., Schmolke, S. R., and Vinod Kumar, A.: A comprehensive Eulerian modeling framework for airborne mercury species: Model development and application in Europe, Atmospheric Environment, 35, 3026-3074, 2001.

Poissant, L. and Casimir, A.: Water-air and soil-air exchange rate of total gaseous mercury measured at background sites, Atmospheric Environment, 32, 883-893, 1998.

Poissant, L., Amyot, M., Pilote, M., and Lean, D.: Mercury water - Air exchange over the upper St. Lawrence River and Lake Ontario, Environmental Science and Technology, 34, 3069-3078, 2000.

Ryaboshapko, A., Bullock, O. R., Ebinghaus, R., Ilyin, I., Lohman, K., Munthe, J., Petersen, G., Seigneur, C., and Wangberg, I.: Comparison of mercury chemistry models, Atmospheric Environment, 36, 3881-3898, 2002.

Seigneur, C., Jwrobel, J., and Constantinou, E.: A chemical kinectic mechanism for atmospheric inorganic mercury, Environmental Science and Technology, 28, 1589-1597, 1994.

Seigneur, C., Abeck, H., Chia, G., Reinhard, M., Bloom, N. S., Prestbo, E. and Saxena P.: Mercury adsorption to elemental carbon (soot) particles and atmospheric particulate matter, Atmospheric Environment, 32, 2649-2657, 1998.

Seigneur C., Karamchandani, P., Lohman, K., and Vijayaraghavan, K.: Multiscal modeling of the atmospheric fate and transport of mercury, Journal of Geophysical Research, 106 (D21), 27795 $27809,2001$.

Shannon, J. D. and Voldner, E. C.: Modeling atmospheric concentrations of mercury and deposition to the great lakes, Atmospheric Environment, 29, 1649-1661, 1995.

Smith, R. M. and Martell, A. E.: Critical Stability Constants, 4: Inorganic Complexes, Plenum Press, New York, 1976.
Sommar, J., Gardfeldt, K., Stromberg, D., and Feng, X.: A kinetic study of the gas-phase reaction between the hydroxyl radical and atmoic mercury, Atmospheric Environment, 35, 3049-3054, 2001.

Thibodeaux, J. L.: Environmental chemodynamics: Movement of chemicals in air, water and soil, (Eds) John wileys \& sons, inc.: ISBN: 0-471-61295-2, 1996.

Tokos, J. J. S., Hall, B., Calhoun, J. A., Prestbo, E. M.: Homogeneous gas-phase reaction of $\mathrm{Hg}^{0}$ with $\mathrm{H}_{2} \mathrm{O}_{2}, \mathrm{O}_{3}, \mathrm{CH}_{3} \mathrm{I}$, and $\left(\mathrm{CH}_{3}\right)_{2} \mathrm{~S}$ : Implications for atmospheric $\mathrm{Hg}$ cycling, Atmospheric Environment, 32, 823-827, 1998.

Travnikov, O. and Ryaboshapko, A.: Modeling of mercury hemispheric transport and deposition, meteorological Synthesizing Centre - East Report, June 2002.

U.S. EPA. Mercury Study Report to Congress. Volume I: Executive Summary, Report number EPA-452/R-97-003. Volume II: An Inventory of Anthropogenic Mercury Emissions in the United States. Report number EPA-452/R-97-004, 1997.

Van Loon, L., Mader, E., and Scott, S. L.: Reduction of the aqueous mercuric ion by Sulfite: UV spctrum of $\mathrm{HgSO} 3$ and its intramolecular redox reaction, J. Phys. Chem. 104, 1621-1626, 2000 .

Wanninkhof, R., Ledwell, J. R., and Broecker, W. S.: Gas exchange - wind speed relationship measured with sulfur hexafluoride on a lake, Science, 227, 1224-1226, 1985.

Xu, X., Yang, X., Miller, D. R., Helble, J. J., Carley, R. J.: Formulation of bi-directional atmosphere-surface exchanges of elemental mercury, Atmospheric Environment, 33, 4345-4355, 1999.

Xu, X., Yang, X., Miller, D. R., Helble, J. J., Carley, R. J.: A regional scale modeling study of atmospheric transport and transformation of mercury. II. Simulation results fot the northeast United States, Atmospheric Environment, 34, 4945-4955, 2000. 